\title{
Attitude of Customers Towards Adopting of Mobile Banking (M-Banking( An Empirical Study From Pakistan)
}

\author{
Dr. Muhammad Irfan \\ Assistant Professor \\ Institute of Banking and Finance \\ Bahauddin Zakariya University Multan, Pakistan \\ Muhammad Hasnain Ali \\ MS ( Business Administration) \\ Institute of Banking and Finance \\ Bahauddin Zakariya University Multan, Pakistan
}

\begin{abstract}
In advancement of technology in the recent years also in the banking sector, this study has conducted for adding the value of advancement in banking and also benefits for the customers. This study has conducted to investigate the attitude of the customers in adoption of Mobile Banking( M-Banking) in Pakistan. Primary data collection has been used based on five point likert scale from the target population that are the users of the Mobile Banking. Data were collected from three hundred users that also have account in different public and private banks. Convenience sampling technique have been used in this study. This study proved the customers have known about the advantages of the $\mathrm{M}$ banking and more satisfied by using the latest technology offered by banks for their accessibility in 24 hours. The main factors- performance expectancy, service quality both have a significant impact on the individual use behavior. Cross-sectional study encompass in it, therefore further should accomplish by incorporating the findings in order to re-collect the results.
\end{abstract}

Keywords : Mobile Banking, Performance Expectancy, System Quality, Customer Satisfaction

DOI: $10.7176 /$ ISDE/10-2-03

\section{Introduction}

Mobile banking is another service for enhancing the technology and in the promotion for building customers satisfaction and the services provided more easy able way to the customers. Increasing resonating in banking as well as in financial sector mobile equipment have capitulated reflective alteration in the promotion of technology (Alalwan, Dwivedi, \& Rana,2017; Gupta, 2013; Lin, 2011; Rana, Dwivedi, Lal, Williams, \& Clement,2017; Shaikh \& Karjaluoto, 2015). The new apps related the M-Banking have been introduced by the smart phones for building the customer relation with the banks (Al-Jabri \& Sohail,2012). Online transfer of money, billing as well as the checking status of amount balance (Alkhaldi, 2016; Arcand, PromTep, Brun, \& Rajaobelina, 2017; Slade,Dwivedi, Piercy, \& Williams, 2015; Slade, Williams, Dwivedi, \& Piercy,2015).

In Pakistan the smart phones dissemination is soaring, and there is a huge thing to see that there are customers that are in awaiting of the latest technology that will offer by the phones in way of apps .Banking Sector and the telecommunication sector of Pakistan both have fashioned for the mobile Commerce. M- banking is helpful for expanding the market and also in the progress of the banking technology. The evaluation of the banking services is also now be complaint through the smart phones. According to Attaa, A. (2012) Now Pakistan has reached 120.5 million the country of subscribers of the Smart phones. This facility with a specified amount that differ from bank to bank offered to their customers by installing app in their phones. But due to the trust building and in reduction of the mistakes it also requires the copies of the statement. It have also reduced the cost and the time saving of the customers, because while using no need to visit bank immediately for payment and transitions purposes. MBanking have also reduced the cost of transport for visiting the ATM. All the necessary and immediately things available on it.

\section{Literature Review}

\subsection{Performance Expectancy}

According to Venkatesh et al., 2003, p.447) "The extent an entity deem to pertain the expertise will help to accomplish inflate in performance. Concerning M-Banking, consumer deem that service spirit in varying the scenery of banking, routing mold, number of situate stopover, and the connections have executed (Dwivedi, Rana, Jeyaraj, Clement, \& Williams, 2017; Bhatiasevi, 2016; Martins, Oliveira, \& Popovic, 2014). Additionally, Bhatiasevi (2016) and Zhou et al. (2010) fulfilled that PE appreciably manipulate the nonstop exploit of MBanking. The persuade of the functions of PE and its comparable (such as alleged virtual gain and superficial expediency on the level of real convention of M-banking services swank declared (e.g. Brown, Cajee, Davies, \& Stroebel, 2003; Sripalawat et al., (2011).Perceived comparative gain optimistically inclined the level of genuine 
treatment of M-Banking. Likewise, studies that adopted TAM (e.g. Sripalawat et al., 2011).

\subsection{System Quality}

According to Zhou, T. (2012) in the elimination of the customer switching its vital to facilitates the customers keeping with the modern facilitation. Chiefly in order to build the trust in the M-Banking. Self efficacy based on the technology it's a factor that creates the trust of using this technology. While in the study of Zhou, T. (2011) firstly the employees of the banking sector must choose or adopt the M-Banking due to it they can able to say the customers about their experience level, in that way its more adopting of M-Banking in order to build expansively about the clients of the Mobile banking users. it's also based on the internet quality of the country that can very country to country.

\subsection{Customer Satisfaction}

According to Farris, P. W., Bendle, N., Pfeifer, P., \& Reibstein, D. (2010) Customer satisfaction is a quantify about foodstuffs moreover services abounding by a corporation congregate or exceed customer anticipation. Customer satisfaction is defined as "the integer of customers, or entitlement of overall customers, reported episode amid a compact, its congregate, or else its services surpass strict aspiration. According to Ling, G. M., Fern, Y. S., Boon, L. K., \& Huat, T. S. (2016) Customer satisfaction was related to those who paid for a product or service and used products and services. Customer satisfaction was known as consumer satisfaction, while the satisfaction of the buyer who bought products or services, but non-consumers of their products and services had a great result of marketing activities, so they Different steps done. Current users of the consumer purchase method have made banks more profitable and profitable. Rather, new customersYoon, C. (2010) said calm and refuge cooperate an imperative role in patron contentment. Freshly the preponderance online banking configuration as assortment of in sequence for instance venture, realty, And delicate fiscal array. This bonus in turn services canister endow with a manner to expand cutthroat lead Online the intact particle customer satisfaction. Further, Due to the continuous encroachment of scything modus operandi on the internet, Clients are still about to secure pecuniary dealings .

\section{Research Model}

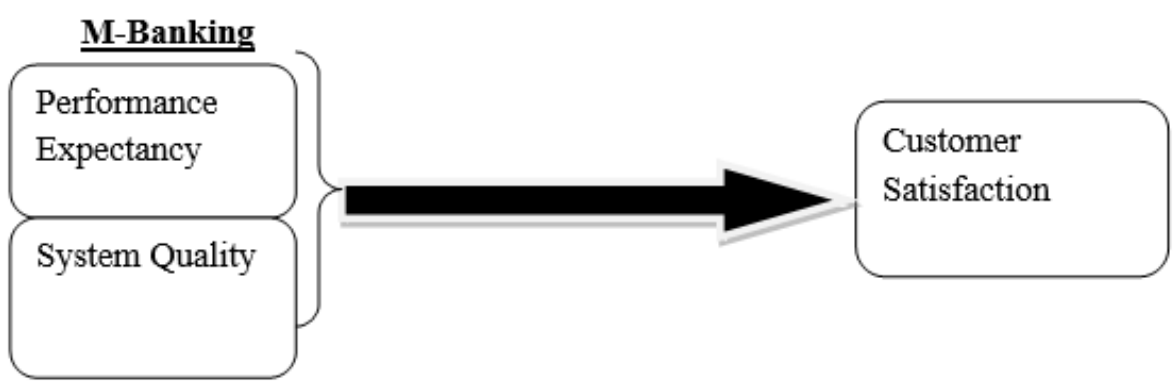

\section{5 .Hypotheses}

H.1 There is a significant relationship between Performance Expectancy and Customer Satisfaction.

H.2 There is a significant relationship between System Quality and Customer Satisfaction.

H.3 Mobile banking has a significant impact on the customers to adopt it also enhance their satisfaction level.

\section{Research Objectives:}

$\checkmark$ To know the customers attitude in the adoption of M-Banking in Pakistan.

$\checkmark \quad$ To Investigate the component of performance expectancy on customer satisfaction through using of MBanking.

$\checkmark$ To know the effect of system quality in the M-banking on the customer satisfaction.

\section{Research Methodology}

Keeping the intention of the study, the data were collected from the major cities of Pakistan with most population because in those cities there are more users of M-Banking keeping this study to generalize. Data were collected from the customers of the four main cities of Pakistan [Lahore, Islamabad, Multan and Faisalabad] to accomplish generalisability. There are three hundred respondents of the questionnaire that are based on five point likert scale. In Non-Probability sampling, convenience sampling was conducted. The target respondents are the customers of different public and private banks using M-Banking service. 
Table 1 . Measurement of variables
Serial No.
Variables
Instruments adopted
1
Performance Expectancy
Venkatesh, V., Thong, J. Y., \& Xu, X. (2012)
2
System Quality
Harrison-Walker, L. J. (2001).
3
Customer Satisfaction
Ho, H. H. (2009).

Table. 2 Reliability of Instruments

\begin{tabular}{|l|c|c|}
\hline \multicolumn{1}{|c|}{ Variables } & No. of Items & Cronbach's Alpha \\
\hline Performance Expectancy( PE) & 10 & .861 \\
\hline System Quality (SQ) & 6 & .761 \\
\hline Customer Satisfaction ( CS) & 12 & .792 \\
\hline
\end{tabular}

According to DeVellis, R. F. (2016) if the value of Cronbach's Alpha is superior than .70 is high intensity of consistency and shows greater reliable of the instruments that have adopted to measure the variables.

Table 3. Demographic Characteristics of the Respondents

\begin{tabular}{|l|l|l|l|}
\hline Variables & Classification & Frequency & Percentage \\
\hline Gender & Male & 212 & 70.7 \\
\hline & Female & 88 & 29.3 \\
\hline & & 300 & $100 \%$ \\
\hline Age Group & Up to 25 years & 77 & 25.7 \\
\hline & $26-35$ years & 91 & 30.3 \\
\hline & $36-45$ & 72 & 24 \\
\hline & More than 45 & 60 & 20 \\
\hline Mobile Bank Account & & 300 & $100 \%$ \\
\hline & Yes & 300 & $100 \%$ \\
\hline
\end{tabular}

\section{Results and Discussion \\ Regression}

Table 4

Model Summary

\begin{tabular}{|l|c|c|c|}
\hline $\mathbf{R}$ & R Square & Adjusted R Square & Std. Error of the Estimate \\
\hline
\end{tabular}

Table 4. 1

\begin{tabular}{|ll|l|}
\hline Model & \\
\cline { 2 - 3 } & & \\
\hline 1 & $\begin{array}{l}\text { (Constant) } \\
\text { Performance Expectancy }\end{array}$ & \\
\hline
\end{tabular}

\section{Coefficients $^{\mathbf{a}}$}

\begin{tabular}{|l|l|l|l|l|}
\multicolumn{2}{|l|}{ Unstandardized Coefficients } & $\begin{array}{l}\text { Standardized } \\
\text { Coefficients }\end{array}$ & T & Sig. \\
\hline B & Std. Error & Beta & & \\
\hline 37.771 & 2.843 & & 13.287 & .000 \\
.117 & .054 & .124 & 2.166 & .000
\end{tabular}

Dependent Variable: Customer Satisfaction

In the effect of performance expectancy on customer satisfaction shows $(\mathrm{P}=0.000, \beta$ value .117$)$ shows the positive relation on the customer satisfaction. Due to the performance expectancy of M-banking the customer satisfaction is high. In Pakistan the usage of M-banking at the initial level but customers are satisfied with the usage of M-banking 
Table 5

Model Summary

\begin{tabular}{|ll|l|l|l|}
\hline R & R Square & Adjusted R Square & Std. Error of the Estimate \\
\hline
\end{tabular}

Table 5.1

\begin{tabular}{|ll|l|l|l|l|}
\hline \multirow{2}{*}{ Model } & \multicolumn{2}{|l|}{ Unstandardized Coefficients } & Standardized Coefficients & T \\
\cline { 3 - 6 } & $\mathrm{B}$ & Std. Error & Beta & \\
\hline \multirow{2}{*}{1} & (Constant) & 43.973 & 2.853 & & 15.414 \\
& System Quality & .112 & .081 & .001 & .000 \\
\end{tabular}

Dependent Variable: Customer Satisfaction

In the effect of System quality on customer satisfaction as the results shows its effect is also positive $(\mathrm{P}=0.000, \beta=.112$ ). It shows the customers are satisfied by the usage of system quality and has a positive effect on their satisfaction level.

\section{Conclusion}

This study has proved the positive attitude of customers in adopting the Mobile Banking. Basically this study has taken from Pakistan. In Pakistan it's just not too much adoption of it. But Customers has positively relate this technology. The findings also that due to the using of M- Banking their satisfaction level also high.

\section{Future Recommendations}

This study have conducted in cross sectional and data have collected only one time. Future research also be in longitudinal by adding more variable like cultural effect and government support also.

\section{References}

Alalwan, A. A., Dwivedi, Y. K., \& Rana, N. P. (2017). Factors influencing adoption of mobile banking by Jordanian bank customers: Extending UTAUT2 with trust. International Journal of Information Management, 37(3), 99-110.

Al-Jabri, I., \& Sohail, M. S. (2012). Mobile banking adoption: Application of diffusion of innovation theory.

Alkhaldi, A. N. ADOPTION OF MOBILE BANKING IN SAUDI ARABIA: AN EMPIRICAL EVALUATION STUDY.

Arcand, M., PromTep, S., Brun, I., \& Rajaobelina, L. (2017). Mobile banking service quality and customer relationships. International Journal of Bank Marketing, 35(7), 1068-1089.

Attaa, A. (2012). Mobile Subscribers in Pakistan Reach 120.5 Million, http://propakistani.pk/2012/12/05/mobilesubscribers-

Baabdullah, A. M., Alalwan, A. A., Rana, N. P., Kizgin, H., \& Patil, P. (2019). Consumer use of mobile banking (M-Banking) in Saudi Arabia: Towards an integrated model. International Journal of Information Management, 44, 38-52.

Bhatiasevi, V. (2016). An extended UTAUT model to explain the adoption of mobile banking. Information Development, 32(4), 799-814.

Bhatiasevi, V. (2016). An extended UTAUT model to explain the adoption of mobile banking. Information Development, 32(4), 799-814.

Brown, I., Cajee, Z., Davies, D., \& Stroebel, S. (2003). Cell phone banking: predictors of adoption in South Africa - an exploratory study. International journal of information management, 23(5), 381-394.

DeVellis, R. F. (2016). Scale development: Theory and applications (Vol. 26). Sage publications

Dwivedi, Y. K., Rana, N. P., Jeyaraj, A., Clement, M., \& Williams, M. D. (2017). Re-examining the unified theory of acceptance and use of technology (UTAUT): Towards a revised theoretical model. Information Systems Frontiers, 1-16.

Farris, P. W., Bendle, N., Pfeifer, P., \& Reibstein, D. (2010). Marketing metrics: The definitive guide to measuring marketing performance. Pearson Education.

Gupta, S. (2013). The mobile banking and payment revolution. European Financial Review, 2, 3-6.

Harrison-Walker, L. J. (2001). The measurement of word-of-mouth communication and an investigation of service quality and customer commitment as potential antecedents. Journal of service research, 4(1), 60-75.

Ho, H. H. (2009). The role of commitment in the relationship between customer satisfaction and customer loyalty in banking industry: Mediating effect of commitment. University of Maryland University College.in-pakistanreach-120-5-million/ (Accessed on December 6, 2012 
Lin, H. F. (2011). An empirical investigation of mobile banking adoption: The effect of innovation attributes and knowledge-based trust. International journal of information management, 31(3), 252-260.

Ling, G. M., Fern, Y. S., Boon, L. K., \& Huat, T. S. (2016). Understanding customer satisfaction of internet banking: A case study in Malacca. Procedia Economics and Finance, 37, 80-85.

Martins, C., Oliveira, T., \& Popovič, A. (2014). Understanding the Internet banking adoption: A unified theory of acceptance and use of technology and perceived risk application. International Journal of Information Management, 34(1), 1-13.

Oly Ndubisi, N. (2007). Relationship marketing and customer loyalty. Marketing intelligence \& planning, 25(1), 98-106.

Rana, N. P., Dwivedi, Y. K., Lal, B., Williams, M. D., \& Clement, M. (2017). Citizens' adoption of an electronic government system: towards a unified view. Information Systems Frontiers, 19(3), 549-568.

Shaikh, A. A., \& Karjaluoto, H. (2015). Mobile banking adoption: A literature review. Telematics and Informatics, 32(1), 129-142.

Slade, E. L., Dwivedi, Y. K., Piercy, N. C., \& Williams, M. D. (2015). Modeling consumers' adoption intentions of remote mobile payments in the United Kingdom: extending UTAUT with innovativeness, risk, and trust. Psychology \& Marketing, 32(8), 860-873.

Slade, E., Williams, M., Dwivedi, Y., \& Piercy, N. (2015). Exploring consumer adoption of proximity mobile payments. Journal of Strategic Marketing, 23(3), 209-223.

Sripalawat, J., Thongmak, M., \& Ngramyarn, A. (2011). M-banking in metropolitan Bangkok and a comparison with other countries. Journal of computer information systems, 51(3), 67-76.

Venkatesh, V., Morris, M. G., Davis, G. B., \& Davis, F. D. (2003). User acceptance of information technology: Toward a unified view. MIS quarterly, 425-478.

Venkatesh, V., Morris, M. G., Davis, G. B., \& Davis, F. D. (2003). User acceptance of information technology: Toward a unified view. MIS quarterly, 425-478.

Venkatesh, V., Thong, J. Y., \& Xu, X. (2012). Consumer acceptance and use of information technology: extending the unified theory of acceptance and use of technology. MIS quarterly, 157-178.

Yoon, C. (2010). Antecedents of customer satisfaction with online banking in China: The effects of experience. Computers in Human Behavior, 26(6), 1296-1304.

Zhou, T. (2011). An empirical examination of initial trust in mobile banking. Internet Research, 21(5), 527-540.

Zhou, T. (2012). Understanding users' initial trust in mobile banking: An elaboration likelihood perspective. Computers in Human Behavior, 28(4), 1518-1525.

Zhou, T., Lu, Y., \& Wang, B. (2010). Integrating TTF and UTAUT to explain mobile banking user adoption. Computers in human behavior, 26(4), 760-767.

Zhou, T., Lu, Y., \& Wang, B. (2010). Integrating TTF and UTAUT to explain mobile banking user adoption. Computers in human behavior, 26(4), 760-767. 